\title{
MEASURING FINANCIAL INTERMEDIATION: A MODEL AND APPLICATION TO THE SLOVAK BANKING SECTOR
}

\author{
Martin Bod’a, Emília Zimková
}

\section{Introduction}

Several factors may be earmarked as vital to smooth and successful working of a developed economy; and one of these factors is the financial system, which provides valuable services to the economy and its stability is always deemed imperative to the stability of the entire economy (e.g. Beck et al., 2014, p. 1-2). This laudatory statement is by no manner diminished by the fact that there is - at it happens - a scattered mosaic of opposing opinions to what extent a sound financial system is actually important to economic growth (Levine, 1997; Thiel, 2001). The key function of the financial system in an economy is "to channel savings to investment" (Thiel, 2001, p. 7), or - putting it differently - to connect agents with surplus funds to those who are in deficit, which are merely two different ways to describe the essence of financial intermediation. The definition is suggestive that financial intermediation should be assessed by comparing how surplus funds are matched against deficit needs. It is chiefly banks whose input to financial intermediation is traditionally most esteemed regardless of the fact that there are also other financial institutions such as insurance companies, asset management firms or brokerage firms acting as financial intermediaries. Hence, it is banks that the focus of this paper lies on.

Financial intermediaries, their reasons of existence or functions and behaviour have been explored deeply and debated in literature, and a number of models have been proposed to study their decision-making or behaviour (see e.g. Bhattacharya \& Thakor, 1993; Freixas \& Rochet, 2008). These models build on elements of microeconomic theory and attempt to inject a dose of rationality into the behaviour of different economic agents, shedding thus light on how they decide and how they time their decisions. Nonetheless, as these models answer different questions, they fail to describe the quality and success with which financial intermediation is accomplished. Following the definition of financial intermediation, the success of financial intermediation reposes in how successfully surplus funds are matched against deficit funds, or how well surplus funds are used to make up for deficit funds. To this end, usually simple ratio analysis is employed to assess financial intermediation, and this analysis in the case of banks relies on the loan-to-deposit ratio that relates the volume of deficit funds covered (in the numerator) and the volume of surplus funds collected (in the denominator). But this ratio, which is usually constructed on an annual basis, confronts the amount of loans made to the amount of deposits taken in a given year, which is the reason that it is merely a "positive" indicator. It misses several aspects of financial intermediation such as that there may be a mismatch in the quality of funds or maturities between the loans made and deposits taken, and says nothing about whether financial intermediation was performed at the most advantageous utilization of available resources in the production framework in which banks operate. The failure of the simple loan-todeposit ratio to account for deviations from the most advantageous, yet attainable, relationship between loans and deposits incites interest of this paper.

In the absence of a methodology suitable for assessing the accomplishment with which commercial banks carry out their intermediation function, the goal of the paper is to explore possibilities of measuring financial intermediation. Centred on commercial banks and the banking part of a financial system, the paper proposes a simple framework for modelling and measuring the attainment in financial intermediation. The framework recognizes that commercial banks are 
economic agents that make free (yet perhaps regulated) decisions in the conditions of multiinput and multi-output production and captures these features of banking operations using the approach of Data Envelopment Analysis [DEA]. Grounded in the principles of DEA modelling, the proposed framework first estimates the production possibility set in a conventional way making therewith full use of observed production activities of individual banks, and then searches for the most convenient (and still attainable) loan-to-deposit ratio. Eventually, the framework translates the accomplishment of financial intermediation into a metric that relates the actually observed loan-to-deposit ratio to the highest attainable loan-to-deposit ratio. The metric is computable for individual banks on a yearly basis, but is equally aggregable for a bank over a longer (or the whole investigated period). Of course, this treatment presupposes that financial intermediation consists especially in creating loans out of deposits, whilst other intermediation outputs (such as securities) are marginal or of no relevance. Such a situation arises in post-Communist economies where developed financial markets do not have a long history and where the traditional model of "deposits-and-loans-only" banking that links depositors and borrowers dominates. For this reason the paper demonstrates the model for Slovak commercial banks and the Slovak banking sector.

The research pursuit embraced here does not serve an end in itself, but its main beneficiaries are commercial banks and regulators. One of the reflections of the past financial crisis is the espousal of stringent regulatory rules promoted under Basel III. These rules entail that links between loans and liquidity of commercial banks are given more attention and are industriously scrutinized by dint of the loan-to-deposit ratio (European Banking Authority, 2017a, p. 62). In consequence, the proposed modelling framework enriches this simple ratio indicator at a methodological level and brings more complexity to measurement of financial intermediation.

The remainder of the paper is structured into four more sections. Section 1 emphasizes main points of the extant theoretical and empirical research aiming at financial intermediation and makes preparatory methodological comments on the direction of research. Section 2 gives a thorough description of the proposed model and is followed by Section 3 that describes and presents an application of the model to Slovak commercial banks for the period between 2008 and 2016. Section 4 discusses the results in greater depth and comments on the properties of the proposed modelling framework whereas the last section concludes.

\section{Research in Financial Intermediation and Loan-to-Deposit Ratio}

To a macroeconomist, the financial system (and especially the banking system) is contributive to economic growth and requisite for the transmission of monetary policy (Yusifzada \& Mammadova, 2015; Beck et al. 2014 , p. 1-2), but to a microeconomist, the financial system (and especially its banking component) is helpful in resource allocation and transformation of financial contracts and securities in the broadest and versatile sense of the word (Freixas \& Rochet, 2008, p. 15). Nonetheless, it is only natural that the financial system is not credited with the purpose of resource allocation alone, but fulfils a variety of functions covering access to a payment system, asset transformation in terms of liquidity, quality and maturity, risk management, information processing and delegated monitoring of borrowers (Bhattacharya \& Thakor, 1993; Freixas \& Rochet, 2008, p. 2, 15-18; Ahn \& Le, 2014, p. 7-9). These functions lower transactions costs of both deficit and surplus economic agents (i.e. debtors and depositors) and there are different competing theories that attempt to explain why financial intermediation exists. These theories are not of import here, but they motivated a number of theoretical models whose goal is to explain the behaviour of financial intermediaries (especially banks) and other economic subjects (i.e. the government, firms and households) under different market conditions or microeconomic settings of the environment. The book by Freixas and Rochet (2008) is an excellent overview of these theories and models and evinces clearly that the contemporary research studies merely the decision-making and reasons of existence of financial intermediaries without making any consideration or assessment as to whether the tasks they perform they handle well or poorly.

The macroeconomically tending strand of literature mostly finds a positive relationship between finance and economic growth and 
it is generally held that "the level of financial development is a good predictor of future rates of economic growth, capital accumulation and technological change" (Levine, 1997, p. 689), although the theoretical reasoning and empirical evidence is somewhat mixed (Yusifzada \& Mammadova, 2015, p. 3-5; Levine, 1997, p. 688-689). A number of studies may be produced devoted to the verification of this relationship referred to commonly as the "finance-growth nexus" (see e.g. the overviews in Levine, 1997; Thiel, 2001, p. 22-23; Law \& Singh, 2014, p. 37; Samargandi et al., 2014, p. 67-68; Arayssi \& Fakih, 2017, p. 108-109; Durusu-Ciftci et al., 2017, p. 291-292). In this regard, measures of financial development can be catalogued into four groups in order to measure financial depth, financial access, financial efficiency and financial stability, which is the methodology proposed by Čihák et al. (2012) and implemented in the World Bank reports on financial development and stability since 2013 (World Bank, 2012). Indicators of financial depth in fact measure the size of the financial sector as they rely on ratios such as deposits to GDP or assets to GDP, private sector credit to GDP (wherein GDP is the conventional abbreviation for gross domestic product). The said indicators may capture the extent with which the financial system serves the economy, but they ignore the attainment in financial intermediation that is in quantitative terms represented by the loan-to-deposit ratio. This indicator is not appreciated sufficiently by the academic community, but is standard in regulatory use by central banks (Office of the Comptroller of the Currency, 2016; DiSalvo \& Johnston, 2017; Národná banka Slovenska, 2017; p. 42; European Banking Authority, 2017b, p. 37). The reason being, there are no less than three interpretations that can be assigned to this indicator and that vary in degrees of relevance to financial stability or to the economy. First, this ratio may be viewed as a statistic assessing a bank's liquidity since it confronts momentarily unavailable allocated funds (total loans in the numerator) with fund requirements that may arise in some period of time (total deposits in the denominator). Second, it measures the extent to which a bank relies on external funding in making loans as it confronts the amount of funds borrowed from depositors at smaller rates (total deposits in the denominator) with the amount of funds re-loaned at higher rates (total loans in the numerator). Third, it is an overall and comprehensive measure of attainment in financial intermediation where the chief possibility of allocating collected funds (deposits) is granting loans and where institutionalized capital markets play a minor role. Even if capital markets are developed, this indicator stresses the loan-making function of commercial banks and captures how successful a bank was in withdrawing savings from individual depositors and supplying them back into the economy in the form conducive to economic activity and growth.

Although the simple ratio of total loans to total deposits is straightforward to compute and interpret and as such it corresponds fully to the task, it suffers from all the deficiencies that plague traditional ratio analysis (see Paradi \& Zhu, 2013, p. 62-63, and the references therein). Furthermore, it is a static measure that captures the relationship between the balance sheet amounts of total deposits and total loans and does not inform whether this proportion might not be more advantageous or to what extent the intermediation potential of banks was utilized in order to create a maximum of loans possibly with a minimum of deposits. This is the realization that gives the impetus to the paper and underlies the model of measuring financial intermediation presented in the next section. The modelling framework is built on the principles of DEA and - assuming a suitable model of banking production - strives to identify in the estimated set of feasible production activities the most convenient factors by which loans can be inflated and deposits can be deflated. The ratio that originates from these factors is an index that identifies feasible slacks in financial intermediation, and is formulated here for individual banks and for the entire sector. The choice of DEA is not happenstance as it is a well-founded flexible benchmarking technique relating observed activities to best practices that are translated into a frontier to which single observations are compared (Bogetoft \& Otto, 2010, p. 17-22). Hence, the methodological apparatus serviced by DEA is of utmost relevance for the present ambition to instil a normative element into measurement of financial intermediation.

Nonetheless, a clear line of distinction must be drawn between the present model of financial intermediation and the set of analytical choices that are known in banking efficiency literature as 
the "intermediation approach" (regardless as to whether they are blended with DEA, stochastic frontier analysis or any other such approach). It is true that in measuring efficiency of banks one of the leading two approaches is the intermediation approach that celebrates the role of a commercial bank as a financial intermediary (see Ahn \& Le, 2014, p. 9-12; Duygun-Fethi \& Pasiouras, 2010, p. 191), and it is also true that the modelling framework espoused here shares much concerning the formation or estimation of the feasible production set based on DEA, but it is implemented in search of the answer to a completely different question. Both the present model of financial intermediation and the traditional model of efficiency measurement under the intermediation approach require that a model of banking production be postulated, and this necessity is common to either of these models. Typically banks are construed as agents who utilize labour force, physical capital, deposits and possibly other resources on the liabilities side of the balance sheet in producing loans, securities and other investments (see Ahn \& Le, 2014, p. 21). Whereas the present model explores to what extent in such a production situation loans can be expanded and deposits contracted so that a production activity remains feasible, the efficiency measurement under the intermediation approach examines to what extent all outputs can be adjusted upwards and inputs suppressed downwards so that a production is still feasible. Furthermore, the index that arises in the former case is more of a productivity measure and the efficiency measure that answers to the latter case is a technical efficiency measure. This is in greater detail explained in the next section.

\section{Proposed Modelling Framework}

The following set-up assumes that there is a panel of observations available for $N$ banks over $T$ time periods. This panel may possibly be unbalanced, but for an arbitrary bank $i$ (where $i \in\{1, \ldots, \mathrm{N}\}$ ) there are $T_{i} \geq 1$ observations available such that $T_{i} \geq 1$ and $\max _{i}\left\{T_{i}\right\} \leq T$. Each bank $i$ in an observed period $t$ (with $t \in\left\{1, \ldots, T_{i}\right\}$ ) transmutes deposits $D_{i t}$ into loans $L_{i t}$ and this transmutation is the essence of financial intermediation. Financial intermediation may be served by utilization or consumption of other $P$ inputs (in addition to deposits) and production of $R$ other desirable outputs (others than loans), which are further considered in vectorized form and denoted by $\mathbf{x}_{i t}=\left(x_{i t}^{P}, \ldots, x_{i t}^{P}\right)^{\prime}$ and $\mathbf{y}_{i t}=\left(y_{i t}^{R}, \ldots, y_{i t}^{R}\right)^{\prime}$. Whenever $P=0$ or $R=0$, these other inputs or outputs can simply be dropped and do not enter the formulations to come. It assumed hereinafter that the production technology remains invariant and without alterations throughout the entire span of $T$ time periods. Naturally, this is barely an innocent assumption, but it is appropriate whenever there are no structural breaks, economic shifts or political upheavals. The decision which years can be deemed as free of structural breaks is obviously judgemental, albeit it may partly be assisted by analytical tools.

Two variants of the model are devised and presented. One variant relates to the accomplishment of financial intermediation of a bank in one time period, whereas the other variant is designed to capture the performance of a bank over the entire span of $T$ time periods. The modification of the latter variant to a smaller subset of time periods is quite obvious and emerges naturally. The fundamental idea is that financial intermediation is successful and effective whenever all deposits are transmuted into loans, or possibly, with a minimum utilization of deposits maximum loans are provided. This suggests that deposits should be deflated to the greatest extent possible whereas loans should be inflated in like manner. One possibility to describe this standard of maximizing the loanto-deposit ratio is to consider a differential additive version of the form $\varphi L-\theta D$, where for universality of presentation - bank and time subscripts are suppressed. It is required that $\varphi \geq 1$ and $\theta \leq 1$, i.e. loans can only be inflated and deposits deflated. Whereas the ratio $L / D$ is the actually observed loan-to-deposit ratio, the ratio $\varphi / \theta$ is intended to represent a measure of wasted potential in financial intermediation and is constructed as a sort-of normalized inflation factor. A value of 1 will suggest that financial intermediation is accomplished at its maximum potential, wherever a value greater than 1 will indicate that there is some ex-post identifiable room for improvement and squandered capacity to financially connect deficit and surplus economic agents. Of course, this interpretation is possible under the proviso that the objective function $\varphi L-\theta D$ is put to an appropriate framework of DEA and confronted against the production possibility set implied by the set of observed production activities. The optimized 
value of the objective function $\varphi L-\theta D$ as such measures the attainable gap between loans made and deposits taken and is a measure of the lost opportunity in financial intermediation. In contrast, $L-D$ is a discrepancy that is actually realized and a negative value indicates that some deposits were not efficiently utilized in financial intermediation, whilst a positive value attesting an overhang of loans over deposits suggests financial intermediation par excellence.

Following these considerations, for bank $o$ at time $\tau$ (where $o \in\{1, \ldots, N\}$ and $\tau \in\left\{1, \ldots, T_{o}\right\}$ ) the linear program that aspires to identify falloffs in financial intermediation reads

$$
\max \varphi_{o \tau} L_{o \tau}-\theta_{o \tau} D_{o \tau}
$$

subject to

$$
\begin{aligned}
& \sum_{i=1}^{i=N} \sum_{t=1}^{t=T_{i}} \lambda_{i t} D_{i t} \leq \theta_{o \tau} D_{o \tau}, \\
& \sum_{i=1}^{i=N} \sum_{t=1}^{t=T_{i}} \lambda_{i t} L_{i t} \geq \varphi_{o \tau} L_{o \tau}, \\
& \sum_{i=1}^{i=N} \sum_{t=1}^{t=T_{i}} \lambda_{i t} \mathbf{x}_{i t} \leq \mathbf{x}_{o \tau}, \\
& \sum_{i=1}^{i=N} \sum_{t=1}^{t=T_{i}} \lambda_{i t} \mathbf{y}_{i t} \geq \mathbf{y}_{o \tau}, \\
& \varphi_{o \tau} \geq 1 \quad \text { and } \quad \theta_{o \tau} \leq 1, \\
& \lambda_{i t} \geq 0 \quad \text { (for } \forall i \in\{1, \ldots, N\}, \forall t \in\left\{1, \ldots, T_{i}\right\} \text { ) } \\
& \text { (and optionally } \quad \sum_{i=1}^{i=N} \sum_{t=1}^{t=T_{i}} \lambda_{i t}=1 \text { ). }
\end{aligned}
$$

The production possibility set is formed in a usual way as the conical or convex hull generated by observed production activities arising by assembling all inputs (deposits and other inputs) and all outputs (loans and other outputs). It depends on whether the convexity restriction requiring that intensity variables sum to unity is enforced by the optional condition in (1d). The imposition of the optional unit sum condition should be guided by conventional wisdom and hinges upon the degree of homogeneity of observed production activities and their operating setting. For reasons that become obvious presently if one wishes to impute the resulting normalized inflation factors $\varphi / \theta$ a reasonable geometric interpretation, this restriction may not be recommendable (complying with variable returns to scale [VRS]) and intensity variables may be desired to be kept free positive (complying with constant returns to scale [CRS]). Throughout the production possibility set a projection upon the part of the frontier (envelope) is sought with the aid of (1) that maximizes the loan-to-deposit ratio. By the stipulation of (1a) to (1d), this projection is achievable according as there is a possibility to generate production activities in line with the axiomatic theory underlying a production model (see e.g. Debreu (1959, p. 39-42), or McFadden (1978, p. 7)). A crucial aspect of (1) is that the objective function is to be maximized so the deviation from the most technically favourable loan-to-deposit ratio is to be identified.

Program (1) is here further modified also to account for the average performance of a bank over the entire period in financial intermediation. Toward this end, the average production quantities for bank $O$ (where $o \in\{1, \ldots, N\})$ are defined in a natural way as $\bar{D}_{o}=T_{o}^{-1} \sum_{t} D_{o t}, \bar{L}_{o}=T_{o}^{-1} \sum_{t} L_{o t}, \overline{\mathbf{x}}_{o}=T_{o}^{-1} \sum_{t} \mathbf{x}_{o t}$ and $\overline{\mathbf{y}}_{o}=T_{o}^{-1} \sum_{t} \mathbf{y}_{o t}$. Then the linear program for this bank $o$ ensues as

$$
\max \bar{\varphi}_{o} \bar{L}_{o}-\bar{\theta}_{o} \bar{D}_{o}
$$

subject to

$$
\begin{aligned}
& \sum_{i=1}^{i=N} \sum_{t=1}^{t=T_{i}} \lambda_{i t} D_{i t} \leq \bar{\theta}_{o} \bar{D}_{o}, \\
& \sum_{i=1}^{i=N} \sum_{t=1}^{t=T_{i}} \lambda_{i t} L_{i t} \geq \bar{\varphi}_{o} \bar{L}_{o}, \\
& \sum_{i=1}^{i=N} \sum_{t=1}^{t=T_{i}} \lambda_{i t} \mathbf{x}_{i t} \leq \overline{\mathbf{x}}_{o}, \\
& \sum_{i=1}^{i=N} \sum_{t=1}^{t=T_{i}} \lambda_{i t} \mathbf{y}_{i t} \geq \overline{\mathbf{y}}_{o}, \\
& \bar{\varphi}_{o} \geq 1 \quad \text { and } \quad \bar{\theta}_{o} \leq 1, \\
& \lambda_{i t} \geq 0 \quad \text { (for } \forall i \in\{1, \ldots, N\}, \forall t_{i} \in\left\{1, \ldots, T_{i}\right\} \text { ) } \\
& \text { (and optionally } \quad \sum_{i=1}^{i=N} \sum_{t=1}^{t=I_{i}} \lambda_{i t}=1 \text { ). }
\end{aligned}
$$

The construction of (2) is identical to (1), but now it the optimization is carried out with average quantities for the bank in question, so the resulting optimized values of the inflation factor $\bar{\varphi}_{o}$ and deflation factor $\bar{\theta}_{o}$ point to the best attainable loan-to-deposit ratio $\bar{\varphi}_{o} / \bar{\theta}_{o}$ that could be realized in financial intermediation.

The ideas embedded in programs (1) and (2) are conveyed graphically in Fig. 1 that gives a geometric portrayal of how these programs implement projections. The figure plots in a twodimensional coordinate system deposits on the 
horizontal axis and loans on the vertical axis. This system answers to the space that remains after the full input-output space (made up of $P+1$ inputs and $R+1$ outputs) is reduced only to deposits and loans. A production activity $[D, L]$ intermediates at a loan-to-deposit ratio of $L / D$. Programs (1) and (2) seek to maximize $\varphi L-\theta D$ with $\varphi \geq 1$ and $\theta \leq 1$ and project the production activity onto the estimated frontier. The plot displays also the estimated "frontier" in the reduced deposits-loans space that answers to the case of CRS introduced by neglecting the optional unit sum restriction in (1d) and (2d). Under CRS production activities can be arbitrarily scaled up or down, which is suggested by the fact that the ray answering to the frontier comes from the origin $O$ and passes through the projection $[\theta D, \varphi L]$. Since through this projection deposits are depressed and loans boosted, the projected activity is identified on the frontier in the left-hand upper area of the original activity. The projected activity operates at a loan-to-deposit ratio of $(\varphi L) /(\theta D)$, which is a $\varphi / \theta$-multiple of the original loan-to-deposit ratio. The higher the distance of a production activity toward the frontier ray (measured, of course, by the angle between the frontier ray and the ray passing through the production activity, or by $\varphi / \theta$ ), the lower success is attained by the production activity in financial intermediation. This interpretation and portrayal of the situation appertains to the assumption of CRS when deposits and loans (as well as other production variables) are theoretically freely scalable. In such a case the loan-to-deposit ratio is to preserve its size irrespective of the concrete position of the production activity. In contrast, VRS stipulate limited scalability and ensure that comparison of loan-to-deposit ratios are rendered only amongst production activities of a similar magnitude of production. To put it differently, under CRS, underperforming loanto-deposit ratios are related to the universally best loan-to-deposit ratio in the sample; whilst under CRS, underperforming loan-to-deposit ratios are related to the loan-to-deposit ratios of units similar in size. For this very reason, CRS might be a preferred modelling choice, albeit their adoption leads to a liberal construction of the production possibility set. Hence, some would be inclined to adopt the assumption of VRS (or in some way to restrict the formation of the production possibility set). Nonetheless, this would be at the expense of losing the interpretation offered by Fig. 1 since the frontier would no longer be represented by rays but by convex envelopes of the observed production activities in the full input-output space (covering also other production variables in addition to deposits and loans).

\section{Fig. 1: Geometric interpretation of programs (1) and (2)}

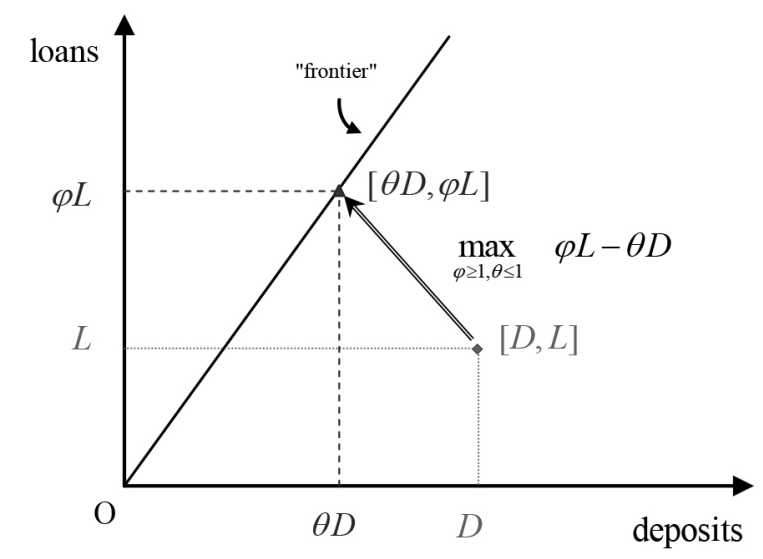




\section{Application to the Slovak Banking Sector}

The model devised for measuring the attainment in financial intermediation presented in the previous section is applied here and demonstrated for Slovak commercial banks for the period from 2008 to 2016. Undoubtedly, the utilization of this model is appropriate for this nine-year period since it represents a compact period of economic development and stability for the Slovak banking sector. The period is marked by preparations of the Slovak banking sector to the euro-adoption before 2008, the very entry to the euro area in 2009 and eventually by successful adaptation to the euro environment. Although the Slovak economy was troubled by manifestations of the Great Recession, the Slovak banking sector remained unaffected and passed these world turbulences without notice. The reason being, although Slovak commercial banks are linked with subsidiary relationships with the countries where the economic and financial events were badly felt, the assets and liabilities of Slovak commercial banks are mostly domestic. The sketched historical circumstances are in greater detail described by Bod'a and Zimková (2017, p. 111-113) who singled out the period after 2008 as a unique stage of development of the Slovak banking sector. Apropos, this line of reasoning affords an innocent assumption of treating different years of the entire nine-year period as structurally coherent and permits pooling data from different years into a larger set of bank-years.

That the demonstration is appropriate for Slovak banks follows also from the fact that their business models are usually footed on traditional depository and creditory services and investments do not dominate in their balance sheets. Furthermore, financial products (such as mutual fund shares) that are sold also by Slovak commercial banks do not appear in the balance sheets and are a minor part of banking activities. Interpreting financial intermediation through depository and creditory operations is thus perfectly apposite in this context and the model of the previous section reducing financial intermediation to taking deposits and providing loans is vindicable.

The data came from separate IFRS financial statements of individual Slovak banking institutions (both commercial banks per se and branch offices of foreign banks) compiled by
TREND Analyses of News and Media Holding, a. s. (the former TREND Holding, s. r. o.). The data sample covered the period of 9 years from 2008 to 2016; yet, the nominal number of commercial banks across these years varied between 8 (in 2016) and 17 (in both 2008 and 2011). In total, the sample contained nominally 122 bank-year observations. The data set had the following representation (whereas parentheses state the number of years for which data were available and brackets with bold fond indicate tags adopted for further presentation): Crédit Agricole Corporate and Investment Bank SA, foreign branch (4) [CAC], Commerzbank Aktiengesellschaft, foreign branch (7) [CAG], Československá obchodná banka, a.s. (6) [CSOB], ING Bank N.V., foreign branch (4) [ING], Istrobanka, a.s. (1) [ISTRO], J\&T Banka a.s., foreign branch (5) [JT], Komerční banka Bratislava, a.s. / Komerční banka, a.s., foreign branch (7) [KOBA], Oberbank AG, foreign branch (8) [OBER], OTP Banka Slovensko, a.s. (9) [OTP], Poštová banka, a.s. (6) [POBA], Dexia banka Slovensko a.s. / Prima banka Slovensko, a.s. (9) [PRIMA], Privatbanka, a.s. (8) [PRIVAT], ABN AMRO Bank N.V., foreign branch / The Royal Bank of Scotland N.V., foreign branch (5) [RBS], Sberbank Slovensko, a.s. (8) [SBER], Slovenská sporitel'ňa, a.s. (9) [SLSP], Tatra banka, a.s. (9) [TATRA], UniBanka, a.s. I UniCredit Bank Slovakia a.s. I UniCredit Bank Czech Republic and Slovakia, a.s., foreign branch (9) [UNICB], Všeobecná úverová banka, a.s. (8) [VUB]. The effective number of observations was affected by missingness of some data points. The yearend balance sheet items stated in thousand $€$ were properly deflated by the implicit price deflator published by Eurostat to assure their comparability. The data set was investigated for a presence of outlying values by dint of the identification method developed by Wilson (1993) without finding out anomalous data points. It is true that the largest banks (SLSP, TATRA and VUB) are somewhat separated from the rest of the data, which may present grounds for preferring the assumption of VRS.

The model of banking production assumed here for Slovak commercial banks is standard and complies with the familiar intermediation approach as it is called in efficiency studies. The model recognizes three inputs and one output. The inputs are labour force measured by the number of employees (NoE), physical capital 
measured by total fixed assets (TFA) and total deposits (TD) and the output is total loans (TL). NoE is expressed in yearly average full-time equivalents, whereas TFA, TD and TL are all expressed as end-year balance sheet amounts (being adjusted by the implicit price deflator to 2005 prices). The insertion of employees and fixed assets into considerations on the side of inputs follows from a classical economic view upon the transformation process, during which factors of production (such as natural resources, the capital stock and labour) are transmuted into outputs. Beyond any doubt, labour force is one of the key factors of productivity growth in the banking sector, and its inclusion through employee numbers takes on relevance as confronting a decreasing trend of the number of employees with an increase of total assets in the Slovak banking industry. The specification of deposits as an input and loans as an output then accords with the premise underlying financial intermediation, i.e. that banks transform deposits into loans. The model of banking production is not discordant from the convention in this area as follows e.g. from Heffernan (2005, p. 474-476) or Ahn and Le (2014, p. 7-9), and implies that $P=2$ and $R=0$ if sticking to the notation introduced at the outset of the previous section.

The basic descriptive statistics for the data sample are reported in Tab. 1 and exhibit a large amount of heterogeneity between commercial banks in the sample, which is a feature displayed by most production data. The sample consists of large and small "normal" commercial banks as well as branch offices of foreign banks. Nonetheless, each data point irrespective of whether it is observed for a large or small bank - provides valuable information about the properties of production operations, which is also the reason why this heterogeneous sample is employed in the demonstration.

Notable differences between the banks in the attained level of financial intermediation are captured by their actually observed loanto-deposit ratios in Tab. 2. This table displays for the 18 banks their year-specific loan-todeposit ratios and the associated non-weighted averages for the entire period. The row labelled as "Total" declares total aggregates for the 18 banks in each of the 9 years. The largest Slovak commercial banks (SLSP, TATRA, VUB, CSOB) reported relatively low levels of loans relative to deposits, whereas smaller commercial banks or branch offices of foreign banks (e.g. CAG, RBS, OBER, KOBA) reported in some years markedly high levels of loans relative to deposits. Admittedly, for the latter class of banks there are discernible fluctuating patterns in loan-todeposit figures implying a change in business policies or business models. The largest loanto-deposit ratio is reported at 6.184 by RBS in 2008 and the smallest figure 0.194 by CAG in 2012. Still, the numbers presented in Tab. 2 fail to identify whether the banks in each of the nine years or over the entire period operated at their best in (this simplified) financial intermediation and whether there is room for amplifying the spread between loans and deposits.

The (estimated) normalized inflation factors $\varphi / \theta$ or $\bar{\varphi} / \bar{\theta}$ that arise in measuring the attainment in financial intermediation by Slovak commercial banks are presented in Tab. 3 for VRS only. On many an occasion when program (1) was utilized for a commercial bank in one particular year, the respective data point was absent, which is indicated by "NA". The results of program (1) are year-specific normalized

Tab. 1: Statistical summary of the data sample

\begin{tabular}{l|c|c|c|c}
\multicolumn{1}{c|}{ Descriptor } & NoE & TFA & TDA & TL \\
\hline Number of values & 122 & 122 & 122 & 122 \\
\hline Minimum & 3 & 0 & 10,510 & 11,617 \\
\hline Maximum & 4,805 & 249,308 & $10,407,245$ & $9,434,668$ \\
\hline Mean & 1,185 & 45,191 & $2,329,640$ & $2,084,887$ \\
\hline Standard deviation & 1,418 & 62,407 & $2,770,231$ & $2,421,488$ \\
\hline
\end{tabular}

Source: own

Note: NoE is expressed in yearly average full-time equivalents, whereas the other three variables are expressed in $€$ of 2005 prices. 
Tab. 2: Loan-to-deposit ratios for banks in the data sample

\begin{tabular}{|c|c|c|c|c|c|c|c|c|c|c|}
\hline Bank & 2008 & 2009 & 2010 & 2011 & 2012 & 2013 & 2014 & 2015 & 2016 & Average \\
\hline CAC & 1.247 & 1.449 & 1.278 & 1.461 & NA & NA & NA & NA & NA & 1.359 \\
\hline CAG & 2.522 & 2.095 & 2.663 & 2.394 & 0.194 & 0.445 & 0.258 & NA & NA & 1.510 \\
\hline CSOB & 0.791 & 0.799 & 0.843 & 0.952 & 0.866 & 0.846 & NA & NA & NA & 0.850 \\
\hline ING & 0.671 & 0.630 & 0.778 & 0.743 & NA & NA & NA & NA & NA & 0.706 \\
\hline ISTRO & 1.162 & NA & NA & NA & NA & NA & NA & NA & NA & 1.162 \\
\hline JT & 2.277 & 1.489 & 1.049 & 1.006 & 0.838 & NA & NA & NA & NA & 1.332 \\
\hline KOBA & 1.972 & NA & NA & 5.304 & 6.388 & 3.535 & 3.873 & 3.803 & 3.544 & 4.060 \\
\hline OBER & NA & 1.105 & 1.691 & 1.877 & 2.385 & 2.387 & 3.342 & 3.618 & 4.036 & 2.555 \\
\hline OTP & 1.196 & 1.058 & 0.989 & 0.968 & 0.911 & 0.951 & 0.895 & 0.933 & 0.981 & 0.987 \\
\hline POBA & 0.460 & 0.462 & 0.477 & 0.499 & 0.589 & 0.562 & NA & NA & NA & 0.508 \\
\hline PRIMA & 1.308 & 1.213 & 1.385 & 0.970 & 0.945 & 0.778 & 0.889 & 0.886 & 0.882 & 1.028 \\
\hline PRIVAT & 0.407 & 0.387 & 0.424 & 0.409 & 0.453 & 0.536 & 0.541 & 0.603 & NA & 0.470 \\
\hline RBS & 6.814 & 5.413 & 1.092 & 0.694 & 0.302 & NA & NA & NA & NA & 2.863 \\
\hline SBER & 0.913 & 1.000 & 0.988 & 0.970 & 0.881 & 0.879 & 1.126 & 0.916 & NA & 0.959 \\
\hline SLSP & 0.666 & 0.742 & 0.733 & 0.791 & 0.807 & 0.814 & 0.872 & 0.900 & 0.907 & 0.804 \\
\hline TATRA & 0.792 & 0.797 & 0.827 & 0.879 & 0.888 & 0.908 & 0.949 & 0.881 & 0.911 & 0.870 \\
\hline UNICB & 1.016 & 1.095 & 0.971 & 1.183 & 1.001 & 1.137 & 1.129 & 1.177 & 1.388 & 1.122 \\
\hline VUB & 0.801 & 0.914 & 0.903 & 0.959 & 0.957 & 0.904 & 0.996 & NA & 1.066 & 0.937 \\
\hline Total & 0.827 & 0.847 & 0.845 & 0.888 & 0.872 & 0.874 & 0.964 & 0.942 & 1.010 & NA \\
\hline
\end{tabular}

Source: own

Note: The meaning of abbreviations is explained above plus "Total" introduces the value aggregated for all these banks. "NA" signals that the data point was not available.

inflation factors $\varphi / \theta$, whereas the results of program (2) are entire-period normalized inflation factors $\bar{\varphi} / \bar{\theta}$. The entire-period factors $\bar{\varphi} / \bar{\theta}$ can be thought of as averages of the yearspecific factors $\varphi / \theta$. By combining the actually observed loan-to-deposit ratios in Tab. 2 with the factors reported in Tab. 3, the feasible loanto-deposit ratios projected for individual banks by models ( 1 ) and (2) can easily be obtained. For instance, PRIVAT in 2011 reported a loanto-deposit ratio of 0.409 , which means that it could only transform about $41 \%$ of its deposits into loans and that it underperformed badly in terms of financial intermediation. When confronted with examples set by other banks, under a somewhat liberal view of VRS, PRIVAT could have made loans as high as to $6.703 \times 0.409=2.741$ times deposits. The results are indicative that for most banks there was an unrealized possibility of improving in financial intermediation and the policy of accepting lower levels of deposits in making higher levels of loans was feasible and advisable. Mostly smaller banks or branch offices of foreign banks could operate realistically at maximum loan-to-deposit ratios in some years; namely, it was CAC (in 2010), KOBA (in 2012, 2013, 2015 and 2016), OBER (in 2010) and RBS (between 2008 and 2012) and SLSP, TATRA, UNICB and VUB (all in 2016). The results in Tabs. 2 and 3 are in accord with business models of foreign branch offices that are grounded in maximizing credit activities whilst utilizing deposits collected in home countries through dense branch networks. Foreign branch offices with a few employees focus mostly on corporate banking and are connected to specific firms from home countries that represent their specific clientele. What is apparent for most foreign branch offices is that both loan-to-deposit ratios and normalized inflation factors exhibit cyclical features (affected mostly by the Great Recession). 


\section{Tab. 3: Results under variable returns to scale}

\begin{tabular}{|c|c|c|c|c|c|c|c|c|c|c|}
\hline \multirow{2}{*}{ Bank } & \multicolumn{9}{|c|}{ Program (1) } & \multirow{2}{*}{$\begin{array}{c}\text { Program } \\
\text { (2) }\end{array}$} \\
\hline & 2008 & 2009 & 2010 & 2011 & 2012 & 2013 & 2014 & 2015 & 2016 & \\
\hline CAC & 3.096 & 2.754 & 1.000 & 2.522 & NA & NA & NA & NA & NA & 2.955 \\
\hline CAG & 2.029 & 2.256 & 1.964 & 1.972 & 13.905 & 4.809 & 5.832 & NA & NA & 3.228 \\
\hline CSOB & 1.797 & 1.736 & 1.647 & 1.458 & 1.602 & 1.641 & NA & NA & NA & 1.627 \\
\hline ING & 4.665 & 5.125 & 4.146 & 4.416 & NA & NA & NA & NA & NA & 4.572 \\
\hline ISTRO & 1.637 & NA & NA & NA & NA & NA & NA & NA & NA & 1.637 \\
\hline JT & 1.432 & 2.246 & 3.235 & 3.329 & 4.036 & NA & NA & NA & NA & 2.855 \\
\hline KOBA & 2.484 & NA & NA & 1.209 & 1.000 & 1.000 & 1.086 & 1.000 & 1.000 & 1.176 \\
\hline OBER & NA & 1.000 & 1.000 & 3.515 & 2.731 & 2.703 & 1.936 & 1.787 & 1.598 & 2.265 \\
\hline OTP & 1.429 & 1.646 & 1.759 & 1.805 & 1.873 & 1.750 & 1.814 & 1.738 & 1.671 & 1.712 \\
\hline POBA & 3.461 & 3.233 & 3.014 & 3.000 & 2.483 & 2.580 & NA & NA & NA & 2.802 \\
\hline PRIMA & 1.231 & 1.289 & 1.141 & 1.659 & 1.729 & 1.988 & 1.753 & 1.823 & 1.859 & 1.536 \\
\hline PRIVAT & 7.898 & 7.471 & 6.081 & 6.703 & 5.881 & 5.123 & 5.202 & 4.859 & NA & 5.701 \\
\hline RBS & 1.000 & 1.000 & 1.000 & 1.000 & 1.000 & NA & NA & NA & NA & 1.359 \\
\hline SBER & 1.827 & 1.697 & 1.702 & 1.681 & 1.787 & 1.736 & 1.396 & 1.702 & NA & 1.678 \\
\hline SLSP & 1.842 & 1.619 & 1.643 & 1.481 & 1.430 & 1.395 & 1.267 & 1.193 & 1.000 & 1.396 \\
\hline TATRA & 1.528 & 1.545 & 1.467 & 1.344 & 1.334 & 1.291 & 1.194 & 1.113 & 1.000 & 1.337 \\
\hline UNICB & 1.394 & 1.315 & 1.432 & 1.199 & 1.392 & 1.235 & 1.240 & 1.185 & 1.000 & 1.246 \\
\hline VUB & 1.563 & 1.339 & 1.325 & 1.209 & 1.202 & 1.270 & 1.130 & NA & 1.000 & 1.220 \\
\hline
\end{tabular}

Source: own

Note: The meaning of abbreviations is explained above. "NA" signals that the data point was not available.

The distribution of the estimated yearspecific normalized inflation factors $\varphi / \theta$ reported otherwise for individual banks and years in Tab. 3 is displayed on the left-hand side of Fig. 2 and testifies that there is a prevalence of normalized inflation factors of a value of 2 at most (a total of 84 bank-years). Moreover, normalized inflation factors higher than 6 are extremely rare. Of practical importance is further the right-hand side of Fig. 2 that shows the distribution of the identified slacks in loans made and deposits taken $\quad(\varphi L-\theta D)-(L-D)=(\varphi-1) L-(\theta-1) D$, which is a measure of wasted intermediation potential in absolute monetary terms. Also this distribution is, up to slight variation, right-skewed and large slacks are identified at a low frequency of bank-years. In most bank-years, the identified gaps in unrealized financial intermediation were up to 1.05 mio. $€$ (the three bars amounting to 93 bank-years).

The imposition of VRS is from a practical viewpoint tantamount to applying a more optimistic outlook on financial intermediation as it contracts the set of feasible production activities and leads to more favourable normalized inflation factors $\varphi / \theta$ and $\bar{\varphi} / \bar{\theta}$. It depends on the beliefs of the analyst whether CRS or VRS are deemed more descriptive. In contrast to the geometric interpretation of the model of financial intermediation offered in the previous section, the lower factors $\varphi / \theta$ and $\bar{\varphi} / \bar{\theta}$ stemming from assuming VRS may be seen more realistic and achievable. One more reason for preference of VRS is that it does without the free scalability of production factors and outputs that would be otherwise implied.

\section{Discussion}

The proposed modelling framework for measuring financial intermediation is founded upon natural assumptions of production theory and views banking enterprise through the lens of the distinguished intermediation approach under which deposits plus other inputs are 


\section{Fig. 2: Normalized inflation factors and slacks under variable returns to scale}

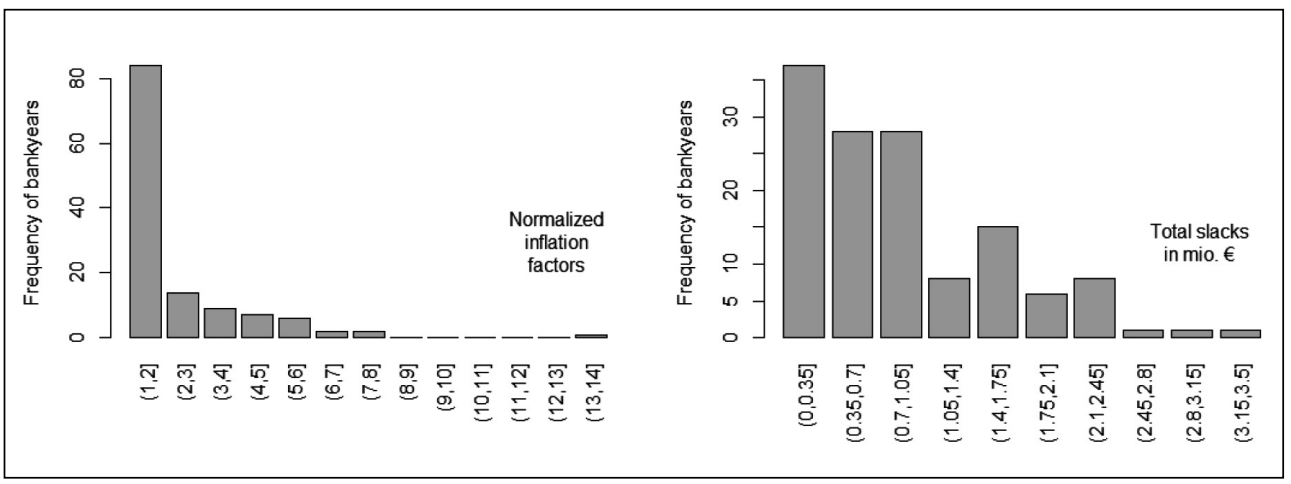

Source: own

transmuted into loans plus (possibly) other outputs. Like DEA efficiency analysis, the proposed framework estimates the production possibility set by a conical or convex hull of observed production activities and attempts a projection throughout the estimated production possibility set. Yet, unlike DEA efficiency analysis, the proposed framework implements the farthest projection by identifying only the largest slacks of loans over deposits. Although this is an approach that draws upon sound grounds and can barely stir up objections, it is not flawless and is bound to be improved in further research. There are a few aspects that merit discussion and call for further explanation:

a) The approach only reviews deposits and loans as the only elements of financial intermediation. It per se overlooks that financial intermediation may collect funds by other (non-depository) borrowing and may provide other (non-creditory) lending as well.

b) The approach seeks to reduce deposits without any further consideration as to whether this is appropriate without limits. (This results from the requirement that $\theta \leq 1$ and $\bar{\theta} \leq 1$.)

c) The approach places no restrictions on the values of the loan-to-deposit ratios without any reflection as to whether they are desirable or economically acceptable. (This results from the fact that no restrictions are posited for $\varphi / \theta$ and $\bar{\varphi} / \bar{\theta}$.)

These three issues are briefly touched in the following text.
Ad a). To a great extent, a schematic representation of financial intermediation as a mere matching of deposits and loans is oversimplistic, but catches the core of the entire process of connecting surplus and deficit economic agents. Whether this is a misinterpretation of financial intermediation or a desirable abstraction depends much on the financial (or banking) system to be analyzed. There are notable differences between financial systems across the world as every financial system emerged from a certain societal and economic set-up. The differences stem traditionally from diverse attitudes toward creditory financing and equity financing, varied propensities to save displayed by households, specific tax environments, asynchronous business cycles, differentiated monetary and economic policies (e.g. different levels of interest rates implemented by monetary authorities). An example is provided by Tab. 4 that shows for the Visegrad Group economies and four other selected (developed) financial sectors ratios of bank loans to deposits for the period 2007-2015. The lowest figures are for Luxembourg, where traditions of their financial system as well as tax and legal configuration motivate savings and households tend to generate high levels of bank deposits. The financial system of Luxembourg specializes in low-risk activities such as fund accounting and private banking what is its main intermediation target for collected deposits. For the period of 9 years, Japan oscillated with loan-to-deposit ratios at about $50 \%$ and the United States [US] 
declined from $80 \%$ in 2007 to about $62 \%$ in 2015 (and this descent occurred in the years of the Great Recession). The Japanese economy is rooted in loan financing since capital markets never dominated in financing economic needs. The figures in Tab. 4 are by reason of traditional built-in high propensities to save and the continuing stagnation of loans taken for financing economic activities. The loan-todeposit ratios in the US were in the entire period affected by the enfeebled creditory capacities of US banks that continued also in the postcrisis period. In contrast, Denmark reported the highest values of the indicator also in Europe. The reason is risk attitudes of Danish banks that increased lending to cyclical industries and to vulnerable households with high debt ratios to boost up profits, but at the expense of easing of credit standards and increased credit risk exposure. A scattered mosaic of trends and levels in traditional financial intermediation oriented in deposits and loans is also readable for the four Visegrad economies. The role of financial intermediaries is and remains traditional in these four economies, Japan and Denmark, but with differing involvement of depository and creditory operations. In contrast, for the US there is a switch to pension funds and mutual funds that force out and replace loans in financial intermediation, which is reported e.g. by Allen and Santomero (2001) and for Luxembourg mutual funds and securities also stand in for banking credit. For these countries the model devised for measuring financial intermediation would be inappropriate because it would miss a substantial part of financial intermediation. Naturally, an eyeball test of loan-to-deposit ratios is not satisfactory, some preliminary knowledge about the situation at hand must be available.

\section{Tab. 4: Loan-to-deposit ratios of banking sectors in selected countries}

\begin{tabular}{l|c|c|c|c|c|c|c|c|c}
\multicolumn{1}{c|}{ Country } & $\mathbf{2 0 0 7}$ & $\mathbf{2 0 0 8}$ & $\mathbf{2 0 0 9}$ & $\mathbf{2 0 1 0}$ & $\mathbf{2 0 1 1}$ & $\mathbf{2 0 1 2}$ & $\mathbf{2 0 1 3}$ & $\mathbf{2 0 1 4}$ & $\mathbf{2 0 1 5}$ \\
\hline Czechia & 0.7030 & 0.7701 & 0.7756 & 0.7640 & 0.7860 & 0.7921 & 0.7748 & 0.7537 & 0.7370 \\
\hline Hungary & 1.2796 & 1.3835 & 1.3040 & 1.1996 & 1.2002 & 1.1172 & 1.0162 & 0.9522 & 0.8546 \\
\hline Poland & 0.8939 & 1.0350 & 1.0639 & 1.0271 & 1.0351 & 1.0260 & 0.9973 & 0.9805 & 0.9688 \\
\hline Slovakia & 0.7564 & 0.8003 & 0.8620 & 0.9398 & 0.9993 & 1.0166 & 0.9883 & 0.9994 & 1.0164 \\
\hline Denmark & 3.0624 & 3.1031 & 3.3182 & 3.5917 & 3.6708 & 3.6444 & 3.5156 & 3.3482 & 3.1902 \\
\hline Japan & 0.5238 & 0.5234 & 0.5185 & 0.5073 & 0.4921 & 0.4834 & 0.4858 & 0.4832 & 0.4765 \\
\hline Luxembourg & 0.1834 & 0.2039 & 0.2490 & 0.2761 & 0.2575 & 0.2626 & 0.2682 & 0.2519 & 0.2399 \\
\hline United States & 0.8148 & 0.7801 & 0.6923 & 0.6398 & 0.6350 & 0.6120 & 0.6038 & 0.6043 & 0.6194 \\
\hline
\end{tabular}

Source: DataMarket.com / World Bank

Ad b). Truthfully, the controversial aspect of the proposed model is that deposits are pressed down and actually squeezed out of the banking system. In point of fact, a certain level of deposits is healthy and deposits should not be deflated without limits or at any cost. This might be implemented by adding a lower limit upon the deflation factor, e.g. as $\theta^{-} \leq \theta \leq 1$ and $\bar{\theta}^{-} \leq \bar{\theta} \leq 1$, where $\theta^{-}$and $\bar{\theta}^{-}$are pre-determined suitably chosen lower bounds. Another option is to reformulate the entire model by requiring that a certain total amount of deposits is to remain in the banking system (which might be well their original total) and by running the optimization for each bank-year (bank-average aggregate) simultaneously. The former avenue seems perhaps more plausible, but either modification deserves further study since the choice of the lower bound for deposits cannot be arbitrary and must be justified.

Ad c). The present model pushes in part to limitless lending, which is but another aspect left for future refinement. Banks cannot lend freely without limits, but they have to be able to lend profitably in a competitive market, while also managing liquidity risks and credit risks (McLeay et al., 2014). Obviously, the loan-todeposit ratio should neither be overly small or exorbitantly high. Too high a value of the ratio may imply insufficient funding of loans by deposits, whereas too low a value may source from inability to utilize deposit in funding business 
plans and from a missed potential of financial intermediation. Conditional on circumstances, there are reasons to prefer values well below 1 or around 1 with some tolerance threshold. In the US the acceptable level is around $0.80-0.90$, which is the benchmark established via a combination of prudence and regulatory requirements (Trefis Team, 2017). In Europe, the loan-to-deposit ratio is scrutinized at the benchmark level 1 at most (green traffic light). Values between 1 and 1.50 are found somewhat risky (yellow traffic light), but values above 1.50 deemed risky (red traffic light). This at least is the methodology of European Banking Authority (2017a, p. 62). Ideally, there should be bounds implemented on the projected loan-to-deposit ratio implemented by upper restrictions on $\varphi / \theta$ and $\bar{\varphi} / \bar{\theta}$, but also this choice should be carefully first reviewed and discussed. All the same, whenever an upper bond is wished for and its value is agreed upon, it can be added "manually" to the results in Tab. 3. The reported normalized factors in these tables that imply (excessively) high loan-to-deposit ratios may simply be truncated "manually".

\section{Conclusion}

The key indicator in banking that depicts the degree of financial intermediation is doubtless the loan-to-deposit ratio, although it seems that this measure is not properly appreciated. Apparently, the academic community does not pay sufficient attention to the loan-to-deposit ratio as opposed to banking practice in which it is heavily employed by national regulators and by commercial banks themselves. The loan-to-deposit ratio is an important descriptor of balance-sheet composition for it provides an instant assessment of the liquidity level of a commercial bank and for this very reason is represented in the CAMELS rating system. Its popularity is not diminished by the fact that it simplifies the balance sheet of financial intermediation to loans (on the assets side) and deposits (on the liabilities side) as a wealthier heterogeneity of investments (on the asset side) and resources (on the liabilities side) emerges in practice. Reducing financial intermediation to transformation of deposits into loans is appropriate in financial sectors where capital markets are underdeveloped or play a conventional minor role.

The present paper explored possibilities of measuring the attainment in financial intermediation of commercial banks and, toward this end, proposed a model that draws upon the principles of DEA and captures the niceties of financial intermediation through the loan-todeposit ratio. Since the model is devised for situations of financial (banking) sectors where financial intermediation rests especially in deposit-taking and loan-making operations, its utilization is most appropriate for commercial banks. The league of the proposed modelling framework with DEA is indisputably its attractive feature which helps to convert a pre-specified set-up of banking production into an estimate of the production possibility set that inevitably contains all feasible activities of financial intermediation. In this set, the most ambitious loan-to-deposit ratio (or, more aptly, the largest gap between loans and deposits) is sought so that an activity is still feasible. This formulation permits identification of a squandered potential in financial intermediation and can be measured by means of normalized inflation factors or amounts of slacks in loans and deposits. The proposed model is under the assumption of variable returns to scale (when the production possibility set is estimated as a convex hull of the observed production activities) applied to Slovak commercial banks to measure their attainment in financial intermediation in the recent period of 9 years.

As it happens, the approach is not unflawed as the paper also discusses some of its limitations. As formulated, the model only relates depository and creditory activities and fits only conditions of some banking sectors without making a proper distinction that different categories of loans are differentiated in terms of outcomes of financial intermediation and contribution to economic growth differently (see e.g. Černohorský, 2017). Whilst pressing down the amount of deposits entering the banking sector, no limits are introduced, which can barely be left free of criticism as some level of deposits is desirable and healthy. Finally, no restrictions are put on loan-to-deposit ratios irrespective of whether the resulting projections are economically defendable. All these issues are challenges and sparks for future work in the field.

The paper was supported by the grant scheme VEGA 1/0859/16 "Dynamics of nonlinear economic processes" of the Ministry of Education, Science, Research and Sport of the Slovak Republic. 


\section{References}

Ahn, H., \& Le, M. H. (2014). An insight into the specification of the input-output set for DEA-based bank efficiency measurement. Management Review Quarterly, 64(1), 3-37. https://dx.doi.org/10.1007/s11301-013-0098-9.

Allen, F., \& Sanomero, A. M. (2001). What do financial intermediaries do? Journal of Banking \& Finance, 25, 271-294. https://dx.doi. org/10.1016/S0378-4266(99)00129-6.

Arayssi, M., \& Fakih, A. (2017). Financegrowth nexus in a changing political region: How important was the Arab Spring? Economic Analysis and Policy, 55, 106-123. htttp://dx.doi. org/10.1016/j.eap.2017.05.001.

Beck, T., Colciago, A., \& Damjan, P. (2014). The role of financial intermediaries in monetary policy transmission. Journal of Economic Dynamics \& Control, 43, 1-11. http://dx.doi. org/10.1016/j.jedc.2014.04.010.

Bhattacharya, S., \& Thakor, A. V. (1993). Contemporary banking theory. Journal of Financial intermediation, 3(1), 2-50. https:// dx.doi.org/10.1006/jfin.1993.1001.

Bod'a, M., \& Zimková, E. (2017). Malmquist index analysis of the recent development of the Slovak banking sector from two different angles. Economic Change and Restructuring, 50(2), 95-131. http://dx.doi.org/10.1007/s10644-0169183-0.

Bogetoft, P., \& Otto, L. (2010). Benchmarking with $D E A, S F A$, and $R$. New York: Springer, 2010.

Černohorský, J. (2017). Types of bank loans and their impact on economic development: a case study of the Czech Republic. E\&M Ekonomie a Management, 20(4), 34-48. https:// dx.doi.org/10.15240/ tul/001/2017-4-003.

Čihák, M. et al. (2012). Benchmarking financial systems around the world [Policy Research Working Paper 6175]. The World Bank. Retrieved February 23, 2018, from http://documents.worldbank.org/curated/ en/868131468326381955/Benchmarkingfinancial-systems-around-the-world.

Debreu, G. (1959). Theory of value: an axiomatic analysis of economic equilibrium. New Haven, London: Yale University Press, 2008 (reprint).

Demirguc-Kunt, A., \& Levine, R. (1999). Bank-based and market-based financial systems: cross-country comparisons [World Bank Working Paper 2143]. Retrieved February 23, 2018, from http://documents.worldbank.
org/curated/en/259341468739463577/Bankbased-and-market-based-financial-systemscross-country-comparisons.

DiSalvo, J., \& Johnston, R. (2017). Banking Trends: The Rise in Loan-to-Deposit Ratios: Is 80 the New 60? [Federal Reserve Bank of Philadelphia]. Retrieved February 23, 2018, from https://www.philadelphiafed.org/researchand-data/banking.

Durusu-Ciftcia, D., Serdar Ispir, M., \& Yetkiner, H. (2017). Financial development and economic growth: some theory and more evidence. Journal of Policy Modeling, 39(2), 290-306. https://dx.doi.org/10.1016/j. jpolmod.2016.08.001.

Duygun-Fethi, M., \& Pasiouras, F. (2010). Assessing bank efficiency and performance with operational research and artificial intelligence techniques: a survey. European Journal of Operational Research, 204(2), 189-198. https:// dx.doi.org/10.1016/j.ejor.2009.08.003.

European Banking Authority. (2017a). Annual report 2016. Retrieved February 23, 2018, from http://www.eba. europa.eu/documents/10180/1879387/ EBA+Annual+Report+2016.pdf.

European Banking Authority. (2017b). Risk Assessment Report - November 2017. Retrieved February 23, 2018, from https://www. eba.europa.eu/documents/10180/2037825/ Risk+Assessment+Report+-+November+2017.pdf.

Freixas, X., \& Rochet, J. C. (2008). Microeconomics of banking (2nd ed.). Cambridge (Massachusetts), London: MIT Press, 2008.

Heffernan, S. (2005). Modern banking (2nd ed.). Chichester (UK): Wiley, 2005.

Law, S. H., \& Singh, N. (2014). Does too much finance harm economic growth? Journal of Banking \& Finance, 41, 36-44. https://dx.doi. org/10.1016/j.jbankfin.2013.12.020.

Levine, R. (1997). Financial development and economic growth. Journal of Economic Literature, 35(2), 688-726.

McFadden, D. (1978). Cost, revenue, and profit functions. In M. Fuss, \& D. McFadden (Eds.), Production economics: a dual approach to theory and applications. Volume I: the theory of production (pp. 3-109). Amsterdam: NorthHolland.

McLeay, M., Radia, A., \& Thomas, R. (2014). Money creation in the modern economy. Bank of England Quarterly Bulletin, Q1. Retrieved February 23, 2018, from https://www. 
bankofengland.co.uk/quarterly-bulletin/2014/ q1/money-creation-in-the-modern-economy.

Národná banka Slovenska. (2017). Správa o stave a vývoji finančného trhu za rok 2016. Retrieved February 23, 2018, from https://www.nbs.sk/sk/publikacie/publikaciedohladu/sprava-o-stave-a-vyvoji-financneho-trhu.

Paradi, J., \& Zhu, H. (2013). A survey on bank branch efficiency and performance research with data envelopment analysis. Omega, 41(1), 61-79. https://dx.doi. org/10.1016/j.omega.2011.08.010.

Office of the Comptroller of the Currency. (2016). Prohibition against interstate deposit production. Description: annual host state loanto-deposit ratios [OCC Bulletin 2016-40]. U.S. Department of the Treasury. Retrieved February 23, 2018, from https://www.occ.gov/newsissuances/bulletins/2016/bulletin-2016-40.html.

Samargandi, N., Fidrmuc, J., \& Ghosh, S. (2014). Is the relationship between financial development and economic growth monotonic? Evidence from a sample of middle-income countries. World Development, 68, 66-81. https://dx.doi.org/10.1016/j. worlddev.2014.11.010.

Thiel, M. (2001). Finance and economic growth - a review of the theory and the available evidence [Directorate General for Economic and Financial Affairs European Union: Economic paper 158]. Retrieved February 23, 2018, from http://ec.europa.eu/economy_finance/ publications/pages/publication884_en.pdf.

Trefis Team. (2017). Loan-to-deposit ratios for largest U.S. banks show signs of recovery in Q1. Retrieved February 23,
2018, from https://www.forbes.com/sites/ greatspeculations/2017/06/13/loan-to-depositratios-for-largest-u-s-banks-show-signs-ofrecovery-in-q1.

Wilson, P. W. (1993). Detecting outliers in deterministic nonparametric frontier models with multiple outputs. Journal of Business and Economic Statistics, 11(3), 319-323. https:// dx.doi.org/10.2307/1391956.

World Bank. (2012). Global financial development report 2013: rethinking the role of the state in finance. Retrieved February 23, 2018, from https://openknowledge.worldbank. org/handle/10986/11848.

Yusifzada, L., \& Mammadova, A. (2015). Financial intermediation and economic growth [William Davidson Institute Working Paper Number 1091]. Retrieved February 23, 2018, from http://deepblue.lib.umich.edu/ handle/2027.42/132992.

doc. Mgr. Ing. Martin Bod'a, PhD. Matej Bel University in Banská Bystrica

Faculty of Economics

Quantitative Methods and Information Systems Department Slovakia martin.boda@umb.sk

prof. Ing. Emília Zimková, PhD. Matej Bel University in Banská Bystrica Faculty of Economics Finance and Accounting Department Slovakia emilia.zimkova@umb.sk 


\section{Abstract}

\section{MEASURING FINANCIAL INTERMEDIATION: A MODEL AND APPLICATION TOTHE SLOVAK BANKING SECTOR}

\section{Martin Boda, Emília Zimková}

The paper proposes a model for measuring the attainment in financial intermediation that answers to situations when functions of financial intermediaries from a macroeconomic viewpoint may be primarily reduced to taking deposits and providing loans (which is characteristic of financial sectors of Post-Communist economies or economies with underdeveloped financial markets). The model builds on the methodology of Data Envelopment Analysis [DEA] since it estimates the production possibility set in a traditional manner as a conical or convex hull of observed production activities. Unlike DEA, the model seeks simultaneously to deflate only deposits and inflate loans to a greatest extent possible so that the production activity of a financial intermediary (typically a bank) remains feasible and stays in the estimated production possibility set. The model translates the identified slacks in deposits and loans into a metric that measures by which factor it is feasible to increase multiplicatively the actually observed loan-to-deposit ratio of a financial intermediary. The metric is computable for individual banks on a yearly basis, but is equally aggregable for a bank over the entire period. In contrast to traditional usage of DEA for efficiency measurement, the proposed model is associated more with the notion of productivity in financial intermediation rather than with the concept of efficiency. The model is presented and demonstrated in a case study of Slovak commercial banks for the period from 2008 to 2016. It is found that only smaller organizational units (smaller banks and branch offices of foreign banks) were in the past few years capable of financial intermediation at the best utilization of their resources, which is an observation relevant from a regulatory point of view.

Key Words: Financial intermediation, loan-to-deposit ratio, data envelopment analysis, Slovak commercial banks.

JEL Classification: D24, G21.

DOI: 10.15240/tul/001/2018-3-010 